\title{
Consequences of the Electoral System in Polish Municipalities - Pathologies and Abuses ${ }^{1}$
}

\begin{abstract}
Pathologies and abuses accompany elections and are connected with the electoral system both in its narrow and broad sense. Moreover, they stem from a human nature and a degree of democratic principles consolidation. Cohabitation is conditioned by the electoral system and, in the case of the proportional allocation of seats, it arises more often than in the majority system with single member constituencies. The phenomenon itself is not always pathological. However, such an adverse situation develops when it comes to clashes, neither substantive nor creative, between the municipal bodies and, in consequence, the interests of the local community are jeopardised. Elections at the municipal level are also accompanied by other pathologies and abuses including: coercing votes when voting by proxy, adding voters to an electoral roll, bringing residents to a polling place, paying for one's votes, preying on the naïvety of voters which can take grotesque forms or brutalising an election campaign caused by the mediatisation of local policy. The above-mentioned phenomena were examined and presented in the paper based on the analysis of statistical data, articles from the local press and, most essentially for the discussed subject, a rich material collected thanks to the in-depth interviews conducted by the authors.
\end{abstract}

Key words: local elections, municipality, cohabitation, electoral system

\section{Introduction}

Tendencies in reforming local government in Europe can be observed in many states, irrespective of their level of democracy, e.g. in Slovakia, Hungary, Germany and Italy. In those countries, in the situation of a marked decline in citizens' trust in public institutions, have occurred a transition from the multi-person to monocratic executive elected by citizens. Poland is not an isolated case and its broadly understood local government electoral system is undergoing a continuous evolution. The most essential changes implemented after 1990

1 This text was produced as part of the National Science Centre's (NCN's) grant OPUS 6, HS5 entitled Cohabitation at the Municipal Level in Poland, agreement No. UMO-2013/11/B/HS5/03537. 
include: the reduction of the number of members of the municipal decision-making and supervisory body (2001), transition from the collegial executive to the monocratic one and from the indirect to direct election of this organ (2002). Besides, the electoral regulations concerning the method of allocating seats were revised on several occasions, which resulted e.g. in the introduction of single member constituencies in municipalities which are not cities with district rights (2011). Profound changes in the Election Code relating to local government, such as the prolongation of the authorities' term of office from four to five years and limitation of executive body's possible terms of office to two, were instituted in 2018. Such fundamental transformations in the broadly understood electoral system can lead to far-reaching consequences for local and regional communities. Therefore, they require ongoing research, diagnosing positive and, especially, negative effects and modelling potential scenarios of the functioning of municipalities in Poland. Part of appearing abuses and pathologies, such as the adding voters to an electoral roll, bringing residents to a polling place by candidates or members of their families or the brutalisation of a local government election campaign, do not directly result from the electoral regulations. They rather stem from the weakness of democracy as well as from the lack of political culture and may occur in any electoral system in the same degree. The others, such as the extortion of votes during voting by proxy or the phenomenon of cohabitation at the municipal level in Poland, are conditioned by the provisions of the Election Code. The introduction of direct elections of the executive body led to the presidential model in municipalities (Larsen 2005, p. 200-203; Zukiewicz 2011,p.300-301) and caused situations that the mayor comes from another committee than the majority in the council. It poses a number of long-term problems which sometimes persist throughout the whole term of office of the local authorities. Interestingly enough, due to the application of different electoral regulations in municipal elections, depending on the size of a municipality and individual elections, it can be established which electoral regulations favour the occurrence of cohabitation. The main aim of this paper is to analyse the above problems and issues. The paper presents only the part of obtained results. On the account of the specific character of the subject of research and the crucial importance of local conditions (situational context), the authors refrain from generalising their conclusions. Nevertheless, as far as the observed processes and effects of the phenomenon of cohabitation at the local level are concerned, they have a similar course and concurrent results, which proves that there are some regularities and trends which can be traced also in other Polish municipalities.

\section{Current state of research and methodology}

The publications on the constitution and organisation of local government, by such authors as B. Dolnicki (2016), Z. Bukowski, T. Jędrzejewski, P. Rączka (2013), A.K. Piasecki (2009), or Z. Leoński (2006), which allow the changes in local government electoral law after 1990 to be traced, provide a valuable source of information about the research topic under ex- 
amination. More detailed analyses of experts and researchers of problems connected with the operation of Poland's local structures, including works on the electoral system, can be found in monographs written by multiple authors and published e.g. on the occasion of the twentieth or twenty-fifth anniversary of the restoration of local government in Poland, e.g. K. Radzik-Maruszak, K. Mieczkowska-Czerniak (2012), K. Popik, B. Szmulik, M. Mazuryk (2016), S. Michałowski, M. Sidor, J. Wasil (2016). Local leadership exerts influence on the emergence of pathologies in local government, too. Political leaderships is the subject of extensive research and described in the body of literature, i.e. R. Rao, N. Berg (2005), while e.g. P. Swianiewicz covers this issue in the context of local government in Poland. The issues connected with local elections, campaigns on the local level and their media coverage, also from the regional perspective, can be found in the books by: A. Turka-Kawa (2013); M. Adamiak-Szysiak, B. Romiszewska, A. Łukasik-Turecka (2016), K. Tybuchowska-Hartlińska (2013), T. Koziełło, D. Szczepański (2017), R. Alberski (2008). Moreover, the following works on cohabitation, regarded as a consequence of the electoral system, proved important for the addressed topic: B. Dziemidok-Olszewska (2010), M. Banaś, P. Lechowicz (2015), (Sidor, Kuć-Czajkowska, Wasil 2017).

Pathologies and abuses resulting from the broadly or narrowly understood electoral system exert a negative impact on the functioning of municipalities in Poland. In order to confirm this hypothesis, the answers to the following research questions were sought: What pathologies and abuses accompany a local government elections in Poland? Which of them are related to a given electoral system? What negative consequences can be caused by the adoption of a specific electoral system?

The following methods were applied so that the hypothesis could be verified and the answers to the research questions could be provided: the institutional and legal one to show the constitutional position of the authorities in the municipality and outline the subject of the electoral system; the statistical one grounded on the analysis of the data from the elections $(2006,2010,2014)$ published on the website of the National Election Commission (PKW), which allowed the authors to find out e.g. the number of Poland's municipalities characterised by cohabitation or municipalities in which the number of voters increased between the first and the second round of election to the executive body. Additionally, the data published by the Central Statistical Office (GUS) were used to achieve this goal. The study of the local press turned out essential for the research project. In-depth interviews (qualitative technique) with the representatives of municipal authorities (mayors, their deputies and councillors) and a local community proved an immensely helpful source of information. In total, over 16 mayors, 11 heads of the municipal or city council, 4 deputy heads of the council, 15 councillors from the ruling coalition or opposition to the executive participated in research. The greatest, 28-person group of the respondents comprised the inhabitants of the examined municipalities. It included, in terms of their profession: 13 members of non-governmental organisations, 6 journalists from the local media, 4 scientific workers, one spokesperson of the office, a village administrator, a firefighter and an 
entrepreneur. In total, from May 2016 to February 2017, 74 interviews were conducted in all kinds of municipalities of six Polish provinces: Warmia-Masuria, Lubusz, Opole, Łódź, Lublin and Holy Cross Provinces. These regions were selected for research due to a high percentage of municipalities with cohabitation recurring after the elections of 2010 and 2014 and newly created in 2014. On account of the limited space, only the most typical and interesting respondents' statements were cited in the paper.

\section{Cohabitation in local elections and how PR increases its probability}

The electoral system can be construed in both a narrow and a broad sense. The former refers to the rules which stipulate the way of determining the election results, so the rule of mandate distribution (majority system, proportional system, mixed system). In the latter one the electoral system can be understood as detailed procedures regarding the mode of election preparation, organisation and vote count (Surówka 2015, p. 97-98). As it was already indicated, the rules of conducting elections at the municipal level in Poland are often subject to changes, while the introduction of direct elections of the executive body in 2002 opened up the possibility of cohabitation at the municipal level which intensity undoubtedly depends on the applied electoral regulations.

In the body of literature cohabitation is mainly described from the point of view of central administration. It occurs when, during the term of the office of president, voters elect the parliament in which a party or coalition of parties opposing the president gains an advantage. The president is then forced to cooperate with the prime minister and government supported by the parliamentary majority from an opposing political camp. In a political and constitutional sense, the notion of cohabitation was formulated in France on the basis of the solutions adopted in the Constitution of the Fifth Republic of France dated 1958 (Skrzydło 1989, p. 219). Cohabitation on the central level have emerged also five times in Poland ${ }^{2}$. The phenomenon of cohabitation arises within the executive power. On the account of the fact that local government administration constitutes its element (Izdebski \& Kulesza 1999, p. 79), the term 'cohabitation', in a political and constitutional sense, can also be used in relation to the municipal level.

Two factors influence the emergence of cohabitation and its intensity in municipalities. The first one is the manner of electing the executive body, the other one - the electoral regulations adopted in the election to councils. Since 2002, cohabitation between municipal authorities has been possible in the case of the mayor and the majority of councillors coming from opposed political camps. The cooperation between these bodies is then forced.

2 It was observed: in the years 1993-1995 (government PSL-SLD, president L. Wałęsa), 1997-2001 (government AWS-UW, president A. Kwaśniewski), 2005 (government PiS, president A. Kwaśniewski), in the years 2007-2010 (government PO-PSL, president L. Kaczyński) and in 2015 (government PO-PSL, president A. Duda) (Dziemidok-Olszewska 2010, pp. 73-90). 
The scale of cohabitation in Polish municipalities in significant. After the 2010 election it was observed in 52\% of units, in 2014 in $49.5 \%$ and as many as $32 \%$ municipalities were affected by this phenomenon both in 2010 and 2014 (Map 1).

The phenomenon of cohabitation was noticed as early as the first term of office after introducing direct election of the executive at the municipal level. Mayors held a majority in councils only in 7 out of 42 cities of over 100,000 inhabitants, while in the remaining 30 towns coalitions were formed and in 5 towns the majority of councillors were in opposition to the municipal administrator (Swianiewicz, Klimska, 2003). In big cities, e.g. Rzeszów

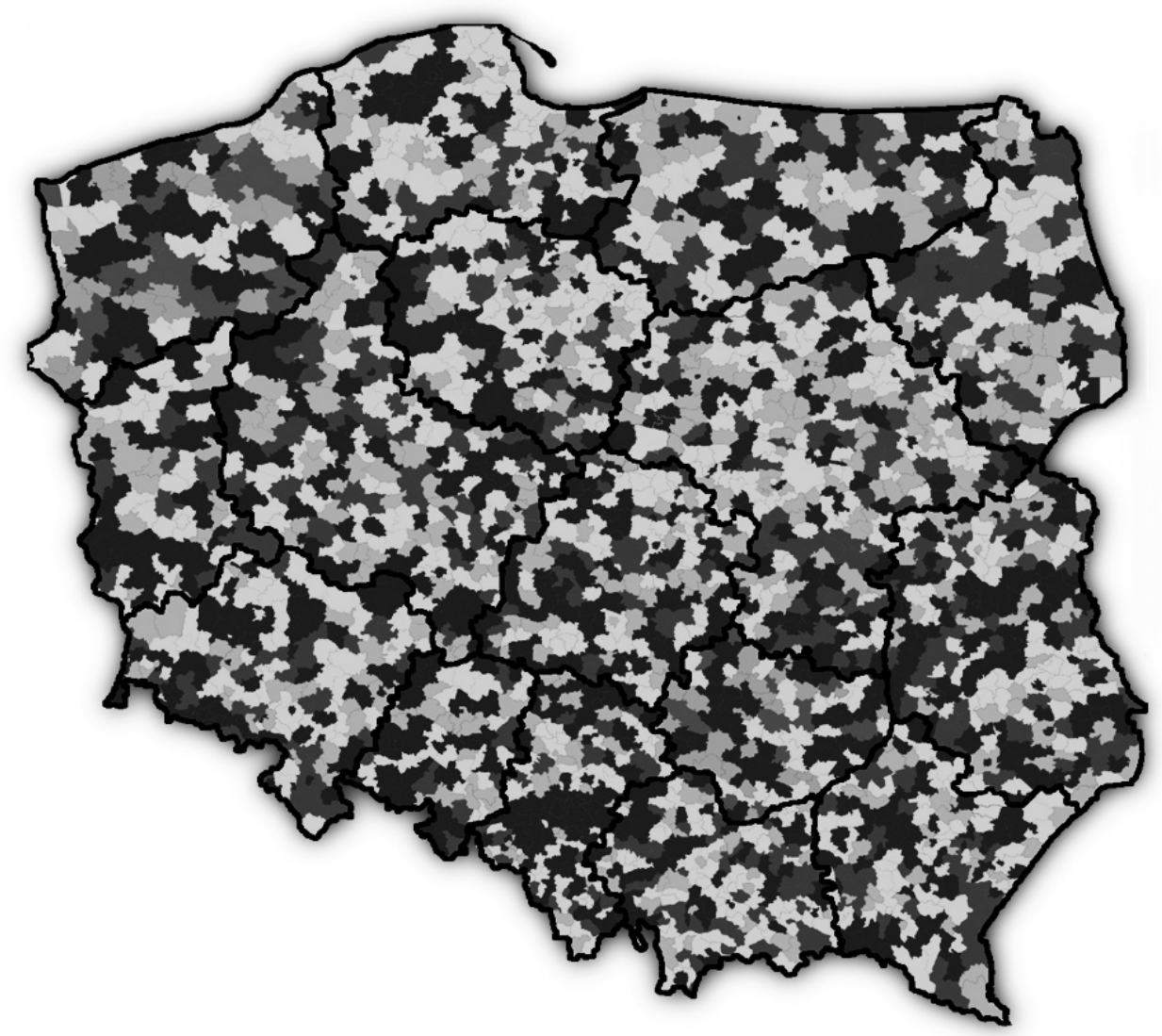

Map 1. Occurrence of cohabitation in Polish municipalities

white - municipalities without cohabitation;

light gray - municipalities under cohabitation in 2010;

gray - municipalities under cohabitation in 2014;

dark gray - municipalities under recurring cohabitation in 2010 and 2014

Source: Sidor, Kuć-Czajkowska, Wasil 2017. 
(Kotarba 2011), the situation has been constantly repeated. The manner of counting votes and allocating seats is also important for the occurrence of cohabitation in Polish municipalities. As it was already pointed out, in 2014 the proportional system was applied only in cities with district rights, while in the remaining municipalities the majority system functioned and the voting was held in single member constituencies. Research indicates that the phenomenon of cohabitation was highly characteristic for the big cities, including provincial ones. In the 2014 elections in the majority of provincial cities (78\%), the mayor did not manage to introduce a sufficient number of candidates from his/her committee into the city's council, which would ensure him/her the support of absolute majority necessary to make decisions. Such a situation took place among others in: Łódź, Kielce, Lublin, Rzeszów, Opole, Bydgoszcz, Katowice Kraków, Poznań and Olsztyn. It is also confirmed by a dark-blue area on Map 1 near Katowice, distinguished by the high concentration of cities with district rights. This fact proves that the proportional system favours cohabitation far more than the majority system (more: Sidor, Kuć-Czajkowska, Wasil 2017).

The above tendency can be observed while analysing the results of the elections in 2010 and 2014 in respect of the emergence of cohabitation in municipalities. In the elections of 2010, as opposed to the elections in 2014, the majority system was applied only in municipalities with up to 20,000 inhabitants, while in the remaining ones the proportional system was used to distribute the seats. Taking a closer look at cohabitation in respect of a municipality type, it should be stated that, as a consequence of the elections of 2010, cohabitation was noted in 227 urban municipalities, 344 urban-rural and 720 rural ones, which makes 1,291 municipalities altogether. After the local elections of 2014, the mayor failed to secure a majority in 184 rural municipalities, 342 urban-rural and 708 rural, which makes 1,234 municipalities altogether (as compared with 2,478 ones in total). Contrasting these two elections, it should be observed that there was a slight decrease (by 57 municipalities) in the scale of the analysed phenomenon in Poland which was accompanied by a more limited application of the proportional system. It mostly concerned urban municipalities (43), in particular those which are not cities with district rights (more: Sidor, Kuć-Czajkowska, Wasil 2017). This aspect also confirms, in a broader time perspective, the influence of the employed electoral systems on how often cohabitation in municipalities occur.

\section{The pathologies connected to cohabitation}

The most difficult situation develops in some municipalities struggling with the conflictual form of cohabitation, which creates numerous problems as far as the cooperation between local authorities and the functioning of the whole unit are concerned. The authorities concentrate on the conflict which usually arise because of personal reasons $(\mathrm{L} 2 \mathrm{u}-1)$, while the affairs of the municipality and interests of its inhabitants recede into the background. 
Part of the respondents (councillors and executive bodies in a municipality) were asked to evaluate the election campaign in 2014. Their answers reflected their subjective feelings, and were grouped in the following way in the chart:

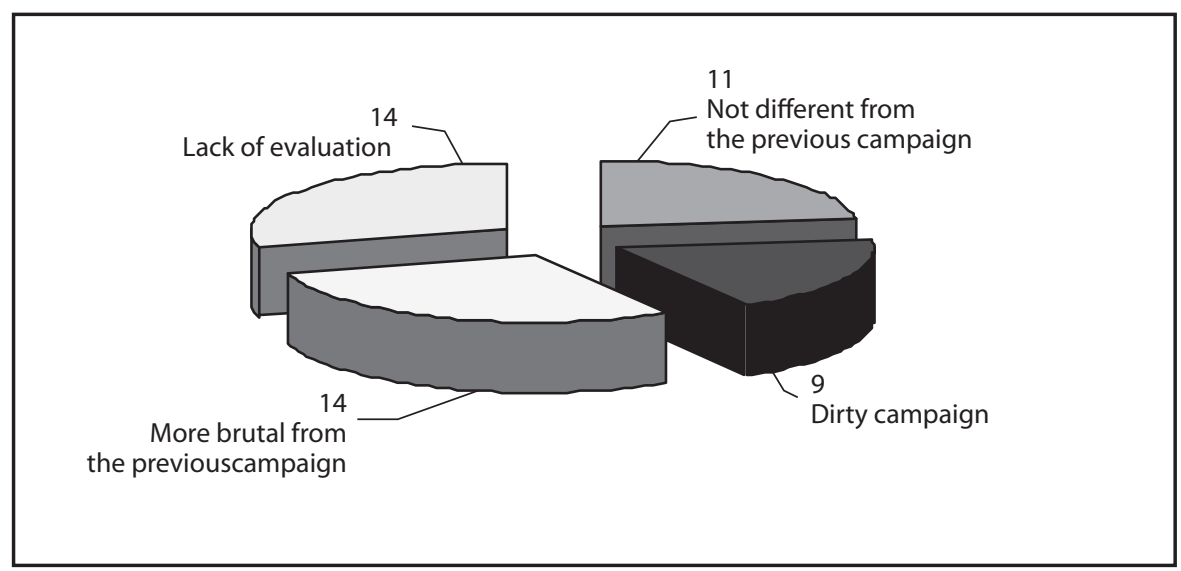

Graph 1. Evaluation of the election campaign (2014)

Source: self elaboration.

- behaviours signifying the lack of the brutalisation of the campaign: normal campaign, decent campaign, not different from the previous ones, actually no campaign - 11 responses;

- behaviours which were a sign of dirty campaign: false accusations, a mess done before the election by staging manifestations in front of the office, newspapers added fuel to the campaign, the bringing of residents to a polling place, unrests accompanied mainly the election of the executive -9 responses;

- the brutalisation of campaign: more brutal, dirty, politicised, more aggressive, mean, stronger that the previous ones, too much emotions - 14 responses

- the lack of evaluation - 14 responses.

As the data shows, almost a half of the responses concerned a dirty campaign and the process of its brutalisation.

Research on cohabitation produced the analysis of the situation of municipalities in which the conflictual co-existence of authorities from various local committees could be described as pathological. The municipality of Wydminy (Warmia-Masuria Province) in the term of office 2010-2014 provides an example here. The municipal council worked to the disadvantage of its inhabitants so that the ideas of the mayor, on principle, were obstructed (e.g. purchasing a bus adapted to the needs of the disabled people). Councillors, in spite of the lack of statutory competence in finance management, tried to take control over the implementation of the municipal budget, which resulted in the reprimand issued by the supervisory body (provincial governor) and judgement rendered in favour of the mayor (more: Sidor, Kuć-Czajkowska, 
Wasil 2017). Conflictual cohabitation is reflected by the fact that the resolution-making and supervisory body adopted, at one of the first sessions of the council, the resolution on mayor's lower remuneration than in the preceding term of office $(02 w, S 2 u-1, S 3 w, L 2 u-1$, $\mathrm{L} 3 \mathrm{u}-1)$. It often has the distinguishing features of emotional blackmail and the challenge of the executive's competence, in particular when such a decision is justified by describing the municipal administrator as a 'trainee mayor' (Barczyński, 2014).

Research on cohabitation demonstrated that municipalities in which the representatives of only two committees entered the council (committee of the executive body being in a minority), or in the case of several committees if one of them had a majority on the council and fiercely opposed the executive, are at risk of conflictual cohabitation. It is easier to work out peaceful cohabitation if representatives of at least three electoral committees, none of which has an absolute majority, entered the council. Unfortunately, even then it can have the hallmarks of pathology and abuses. In compliance with the theory of building e.g. a minimal victorious coalition (Riker, Ordeshook, 1968; Betkiewicz, 2011), the efforts to establish relations indispensable for the effective management of the municipality are targeted at a number of people who will ensure a one-vote majority on the council. Such a situation, arising in the case of peaceful cohabitation too, paves the way for abuses and pathologies. In the part of municipalities in the electoral period, especially in big cities, official talks including the conclusion of coalition agreements are held. However, in the absence of an opportunity to forge a permanent alliance according to the above rules, municipal administrators resort to less formal methods, sometimes verging on the illegal. Councillors or the members of their families are employed in municipal companies and organisational units, which results in their transition to the camp of the mayor: There are such councillors who always bore grudges, were always in the opposition, headed the council, fought for a number of different things and then, all of a sudden, got up in the morning and quitted their club. Such stories also happen. If we could talk about the details, the police or public prosecutor's office would have to be called [...]. Officially, you cannot do anything harmful to such a councillor but this person has an aunt, some distant relative or somebody else, and there are municipal companies (S10-1). In the case of employing, in the previous terms of office, a member of the resolution-making and supervisory body in the units subordinated to the municipality, some councillors go over to the mayor's camp because of fear of losing their job: This mayor kept trying to attract councillors and was quite effective in it: e.g. he managed to persuade a colleague of mine who was one of us (because we held a large majority) and worked at school. The mayor, who had won the election but wasn't supported by many councillors, started to 'silence' the man and urged him to change sides, suggesting that he would be fired otherwise [...]. Another councillor is a stoker in some other school and he would get sacked too. At the first session the councillor-stoker was present. He didn't manage to come to the second one. He called us up saying that a new stove was being installed in his school and he had to be there. At the next session he was also absent, he didn't know how to behave. I called Miss Ania [councillor's wife] and asked her why he 
didn't come, if he was ill or something else? 'Mr [name], he is all of the tremble and I am sending him to see a doctor.' Perhaps he felt stressed out because, you know.... As a result he switched sides and is now there [in the coalition] and still works at school (L2u-2). Besides, in the interviews, respondents mentioned the attempts to intimidate councillors and intrude them at home (L2u-1).

\section{Other pathologies in the election campaign of 2014}

Characterising the electoral system to the municipal authorities in the broad sense it ought to be said that in municipalities which are not cities with district rights the system was based on simple procedures in the 2014 elections. The majority voting was held in single member constituencies, a voter had a categorical vote (one vote cast for a specific candidate) and, finally, there were no electoral thresholds. In cities with district rights the voting took place on the principles of the proportional system with a 5-percent threshold and a voter disposed of a categorical vote. Such formulated election of the executive in all municipalities was conducted under the same conditions. The voting by proxy was introduced (Kodeks wyborczy 2011). The election rules could favour abuses and pathologies in both the elections campaign and the election itself. They could influence the election results and sometimes would lead to charges of electoral frauds.

During the in-depth interviews respondents were asked about the course of the election campaign in 2014 and its assessment as compared with those in e.g. 2010, 2006 and 2002. In municipalities in which occurred the conflict resulting from cohabitation, respondents stressed that the election campaign underwent brutalisation: The whole election campaign was more aggressive, ruthless and very much politicised (W3u). There were more behaviours close to bad taste or a breach of law. One of those worth mentioning was adding voters to an electoral roll: He seeks his own voters, in spite of evidently weak support, often using people from the outside by e.g. adding them to electoral rolls - he knows how to do it ( $₫ 4 \mathrm{w})$. Such a situation arose most often in units in which the second round of the executive election had to be organised. The number of inhabitants of the municipality of Sawin (Lublin Province) increased by almost 50 people in the above-mentioned period of two weeks (PKW), which equals the total number of new residents in the whole 2014 in this municipality (GUS). According to the local community, this strategy was adopted by the mayor who strove for re-election (Lublin.Wyborcza.pl, 2014). In spite of the trick, the election was won by his rival by about 150 votes (PKW) and the matter remained just one of media news reports. However, adding voters to an electoral roll in the municipality of Tarłów (Holy Cross Province), in which the mayor was re-elected in the second round of elections by only 6 votes, ended up in court. The municipal administrator, his family, several officials and one of local parish priests were in the dock. Some of them were charged with wheedling support for the incumbent mayor by taking advantage of proxy voting (Zemsta, 2017). 
The brutalisation of the campaign in 2014 was also noticeable in respect of vilifying rivals for the function of a councillor as well as the executive ${ }^{3}$. In big cities, in which candidates ran for the office of mayor and belonged to political parties, opinions about competitors were officially expressed and electoral materials were signed by their authors. For this reason, if electoral committees slandered their competitors, legal actions could be taken under the electoral procedure, i.e. the judgement was rendered within 24 hours (Election Code 2011). It can be illustrated by a lost court trial of a PiS candidate for mayor of Lublin. He was obliged, by virtue of a court decree, to publish a correction of the statement defaming his rival and pay PLN 10,000 for social purposes (Dunajska, 2014).

However, it turned out more difficult to take a legal action under the electoral procedure by candidates from smaller municipalities. The development of information technology and the possibility of e.g. printing electoral materials on home printers allowed information on the Internet to be anonymously posted and leaflets slandering rivals to be published without naming their authors: It was a negative campaign. There were famous leaflets, I think, there's nothing secret about it. The leaflets which were distributed here in [name of the municipality] by one person, or actually we don't know by whom, were illustrated with the crossed-out face of the present mayor, so it was a slight to the reputation of that man as a human being, let alone a public person (Ł1u-2). Another respondent described the rivalry between candidates for councillors: I experienced the brutalisation of the campaign when somebody in my constituency issued leaflets, unsigned and produced on an ordinary printer, dropping them to letter boxes in blocks of flats. Of course, they were offensive and untrue. I notified the law enforcement authorities about it under the electoral procedure. It was difficult to find the perpetrator in spite of video surveillance showing who entered the building etc. It was 4 days before election silence. To all intents and purposes, I didn't even have the time to comment on the situation, but anyway it was pointless. This brutalisation was so increased that there was virtually no time left for reaction. It happened for the first time. I think that the fact of groundlessly accusing the rival of being a thief or bandit influenced the election outcome (L3u-2).

Bribing councillors with posts by the executive in order to induce them to form a ruling coalition at the early stage of the term of office has already been described in the present paper. Candidates for local government used similar methods in relation to voters. Respondents even claimed that on the account of this fact substantive arguments in local government elections were not necessary: Sometimes I also went from door to door in an election campaign, tried to talk with people. I was convinced that a programme is crucial for each candidate. Afterwards I got to know that it is actually not necessary to have a programme $(€ 2 \mathrm{u})$. In the course of an election campaign it paid off for candidates to manipulate voters, which often meant downright buying their votes: It's such a primitive manipulation of electors and, what's even sadder, they're taken in, they believe in what somebody has promised

\footnotetext{
${ }^{3}$ Examples of manipulation in an election campaign are described by Szalkiewicz 2014, pp. 161-265.
} 
them. They believe in what they have been told and act like a flock of sheep trying to get some profits from these promises. They aren't aware, or don't want to be aware, that these promises have just one aim - to make people go to the polls and cast their vote for a proper candidate. For me it's sad but this is how this world functions (Wlu). Pretenders to the office of mayor promised specific benefits, e.g. coal (L2u-1) or a pension rise, in return for backing them up in an election. I must say that she [candidate for the mayor position] was stubborn because she visited all the villages, shook hands with everyone, promising that if people voted her in, she would boost their pensions. Such were her promises. Afterwards, old ladies came to the town hall and asked in which room their pension would be increased. When I heard it for the first time, I thought it was a joke. I went downstairs to the girls and they told me that several people have already come asking about pension rise $(\mathrm{U} 2 \mathrm{u})$.

Moreover, the method of the in-depth interview revealed municipalities in which inhabitants were brought to polling stations. Such techniques, typical for authoritarian systems or those characterised by weak democracy, were deep-rooted and generally accepted in the described community: In the election campaign I was mostly astonished by the fact that candidates, I think the majority of them did so but I'm not sure if it was legal or not, they gave voters a lift, bribed them. I was surprised by that. As I was a candidate for the first time (three terms of office ago), I set up a committee, came up with a slogan etc. On the election day my son-in-law and me went to a second-hand car sale. The people I met there were startled: 'What are you doing here? You've come to the second-hand car sale instead of driving your voters?' And, in fact, I was defeated by six votes. So when I stood for election for the second time, I drove two elderly people to a polling station. I did so because otherwise they wouldn't simply have managed to come - so I gave them a lift $(€ 4 \mathrm{u}-2)$. In the municipality referred to by the respondent the voter turnout in 2014 amounted to $61 \%$ (PKW), significantly exceeding the national average $-47 \%$ (PKW), which can only lend credence to the above information.

\section{Conclusions}

Pathologies and abuses can be divided into those which accompany elections and are connected with the application of a specific method for allocating seats and, in a broader sense, those related to a human nature, the degree of democratic principles consolidation thus appearing irrespective of a type of the electoral regulations. The research demonstrates that cohabitation depends on the electoral system and emerges more frequently in the case of a proportional allocation of seats than in the majority voting system with single member constituencies. The phenomenon itself is not always pathological. It more frequently evolves in this direction when there are conflicts, neither substantive nor creative, between the municipal authorities and, in consequence, the interest of a local community suffers.

Regardless of a type of the employed electoral regulations, pathological behaviours and electoral frauds in Polish municipalities are rather conditioned by a human nature, insularity of a local community and fragility of democratic principles. The data collected by the 
National Election Commission indicate that the most common strategy to boost the chances of one of the candidates in the elections, especially to the executive, is adding inhabitants to an electoral roll between the first and the second round of the elections. The research also reveals the practice of bringing residents to a polling place in some municipalities. Besides, abuses happened in the case of voting by proxy when the power of attorney was swindled out of a voter and his/her vote was casted out without regard for voter's actual preferences. From the analysis of successive local election campaigns it appears that a local government election campaign is getting more and more brutal, which is mostly due to the development of information technology, the universal use of media (including social media) and the possibility of a quick and anonymous printing of election materials slandering rivals.

The research conveys an image of local Poland where people are cheated by candidates in local elections, which confirms a low level of the awareness of the society. The inhabitants are not fully aware of tasks for which the structures of local government bear responsibility. Paradoxically, pathological practices and behaviours (bringing residents to a polling place, paying for one's vote) are regarded as the status quo and not objected to as the majority of people in a given municipality act in such a way. All the listed and described pathologies and abuses provoke conflicts between the municipal authorities during the term of office. Antagonisms and vain disputes exacerbate the deprofessionalisation of the part of local leaders who concentrate on political fights, thus producing negative effects for a local community, sometimes throughout their entire term of office.

\section{Reference}

Adamik-Szysiak M., Romiszewska B., Łukasik-Turecka A. (2016). Barwy wyborczej kampanii samorzadowej 2014 roku na Lubelszczyźnie. Lublin: Wydawnictwo UMCS.

Alberski R, ed. (2008). Wybory samorzadowe na Dolnym Ślasku w 2006 roku. Wzorce rywalizacji w lokalnych systemach politycznych. Wrocław: Wydawnictwo Profil.

Banaś M., Lechowicz P. (2015). "Koabitacja a trwałość gabinetów koalicyjnych w Polsce po 1991 roku". Polityka i Społeczeństwo, nr 4.

Barczyński J. (30.12.2014). "Nowy wójt gminy Sawin z najniższą pensją. «Sprawdzi się, zarobi więcej»”, http://www.dziennikwschodni.pl/chelm/nowy-wojt-gminy-sawin-z-najnizsza-pensja-sprawdzi-siezarobi-wiecej,n,141229715.html.

Betkiewicz W. (2010). "Determinanty składu koalicji w sejmikach wojewódzkich w 2010 roku. Cele programowe czy stanowiska w zarząach?” In Nalewajko E. (Ed.), Radni sejmików wojewódzkich. Role $i$ konteksty. Warszawa: Wydawnictwo PAN.

Bukowski Z., Jędrzejewski T., Rączka P. (2013). Ustrój samorzadu terytorialnego, Toruń: Towarzystwo Naukowe Organizacji i Kierowania "Dom Organizatora”.

Dolnicki B. ed. (2016). Ustawa o samorzązie gminnym: komentarz. Warszawa: Wolters Kluwer SA.

Dunajska, A. (2014). "Procesy w trybie wyborczym. Jedna wygrana Żuka, jedno zwycięstwo PiS", http:// www.polskatimes.pl/artykul/3646988,procesy-w-trybie-wyborczym-jedna-wygrana-zuka-jednozwyciestwo-pis,-1,11,id,t,so,nk.html. 
Dziemidok-Olszewska, B. (2010).“Koabitacja w perspektywie porównawczej (na przykładzie V Republiki Francuskiej i Polski)”, In Adaptacja - reforma - stabilizacja. Przestrzeń publiczna we wspótczesnych systemach politycznych, T. Koziełł, P. Maj, W. Paruch (Eds.). Rzeszów: Wydawnictwo UR.

Izdebski H., Kulesza, M. (2004). Administracja publiczna, Liber Sp. z o.o. Warszawa.

Jeziński, M., Peszyński, W., Seklecka, A. (Eds.) (2013). Wybory 2010. Media i marketing polityczny, Toruń: Wydawnictwo Naukowe Uniwersytetu Mikołaja Kopernika.

Kotarba, B. (2011). Walka polityczna na forum Rady Miasta Rzeszowa w latach 2002-2010, Rzeszów: Wydawnictwo URz.

Kotras, M. (2009). Przywództwo polityczne na poziomie regionu. Przykład województwa łódzkiego, Łódź. Koziełło, T., Szczepański, D. (Eds.) (2017). Geografia wyborcza Polski. Interpretacje postaw i zachowań obywateli. Rzeszów.

Larsen, H.O. (2005). “Transforming political leadership: Models, trends and reforms”. In R. Berg, N. Rao (Eds.), Transforming political leadership. Nowy Jork: Palgrave Macmilan.

Leoński, Z. (2006). Samorzą terytorialny w RP. Warszawa: Wydawnictwo C.H. Beck.

Michałowski, S., Sidor, M., Wasil, J., eds. (2016). 25 lat samorzadu terytorialnego $w$ Polsce - bilans doświadczeń. Lublin: Wydawnictwo UMCS.

Mieczkowska-Czerniak K., Radzik-Maruszak, K., eds. (2012). 20 lat samorządu terytorialnego w Polsce sukcesy, porażki, perspektywy. Lublin: Wydawnictwo UMCS.

Model przywództwa (2006). Piasecki K.A. (red.). Kraków: Wydawnictwo “Profesja”.

Mouritzen, E., Svara J. (2002). Leadership at the Apex. Pittsburgh: University of Pittsburgh Press.

Piasecki, A.K. (2007). Samorzą terytorialny i wspólnoty lokalne. Warszawa: Wyd. Naukowe PWN.

Piasecki, A.K. (Eds.) (2008). Model przywództwa. Kraków: Wydawnictwo Profesja.

Pierzchalski, F. (2013). Morfogeneza przywództwa politycznego. Bydgoszcz: Wyd. Uniwersytetu Kazimierza Wielkiego.

Popik, K., Szmulik, B., Mazuryk M. (Eds.) (2016). 25 lat funkcjonowania samorzadu terytorialnego w Polsce - teoria i praktyka. Lublin: Wyższa Szkoła Ekonomii i Innowacji.

Riker, W., \& Ordeshook, P. (1968). A Theory of the Calculus of Voting. American Political Science Review, 62(1), 25-42. doi:10.1017/S000305540011562X.

Sidor, M., Kuć-Czajkowska, K.A., Wasil, J. (2017). Koabitacja na poziomie gminnym w Polsce, Warszawa. Wyd. Socholar.

Skrzydło, W. (1989). “Ustrój polityczny V Republiki w okresie kohabitacji (1986-1988)”. Studia Prawnicze, $2-3$.

Surówka, A. (2015). “Zmiana systemu wyborczego do rad gmin a łączność z wyborcami”. Polityka i Społeczeństwo, nr 3(13), p. 96-112.

Swianiewicz, P., Klimska, U. (2003). “Kto rządzi gminą i jak? Lokalni liderzy polityczni w teorii i praktyce samorządów w Polsce”, Studia Regionalne i Lokalne, nr 4(14).

Szalkiewicz,W.K. (2014). Praktyki manipulacyjne w polskich kampaniach wyborczych. Kraków-Legionowo: Edu-Libri.

Śmigielska, J. (2004). Teatr władzy lokalnej. Warszawa: Wydawnictwo TRIO.

Turska-Kawa, A. (2013). Osobowościowe uwarunkowania zachowań wyborczych. Studium województwa ślaskiego. Toruń: Wydawnictwo Adam Marszałek.

Tybuchowska-Hatlińska, K. (Ed.) (2013). Wybory do samorządu terytorialnego w Polsce. Dwadzieścia lat doświadczeń w subregionie ciechanowskim. Toruń: Europejskie Centrum Edukacyjne.

Ustawa z 5 stycznia 2011 r. Kodeks wyborczy, Dz. U. 2011, nr 21, poz. 112 z późn. zm. 
Zemsta, E. (2017). “Są zarzuty dla wójta gminy Tarłów!", http://www.echodnia.eu/swietokrzyskie/wiadomosci/opatow/a/sa-zarzuty-dla-wojta-gminy-tarlow,12250007/.

Żukiewicz, P. (2011). Przywództwo polityczne. Teoria i praktyka, Warszawa: Difin.

\section{Authors}

\section{Justyna Wasil, $\mathrm{PhD}$}

University of Maria Curie-Skłodowska, Faculty of Political Sciences, Department of Local Government and Politics,

Contact details: Pl. Litewski 3, 20-080 Lublin, Poland

e-mail: justyna.wasil@poczta.umcs.lublin.pl

\section{Katarzyna A. Kuć-Czajkowska, PhD}

University of Maria Curie-Skłodowska, Faculty of Political Sciences, Department of Local Government and Politics,

Contact details: Pl. Litewski 3, 20-080 Lublin, Poland

e-mail: katarzyna.kuc-czajkowska@poczta.umcs.lublin.pl

\section{Monika Sidor, $\mathrm{PhD}$}

University of Maria Curie-Skłodowska, Faculty of Political Sciences, Department of Local Government and Politics,

Contact details: Pl. Litewski 3, 20-080 Lublin, Poland

e-mail: monika.sidor@poczta.umcs.lublin.pl 